\title{
Kısırlaştırılan Kedilerde Krom Pikolinatın Ağırlık Artışı, Morfometrik Ölçümler ile Kan Lipid ve Leptin Seviyelerine Etkisi**
}

\author{
Öznur ASLAN ${ }^{1}$, Berrin KOCAOĞLU GÜÇLÜ2², Fatma UYANIK ${ }^{3}$, Yücel ÇAM ${ }^{1}$, Kazım GÜVENÇ4, \\ Kutlay GÜRBULAK ${ }^{5}$
}

\author{
${ }^{1}$ Erciyes Üniversitesi, Veteriner Fakültesi, İç Hastalıkları Anabilim Dalı, Kayseri, Türkiye. \\ ${ }^{2}$ Erciyes Üniversitesi, Veteriner Fakültesi, Hayvan Besleme ve Beslenme Hastalıkları Anabilim Dalı, Kayseri, Türkiye. \\ ${ }^{3}$ Erciyes Üniversitesi, Veteriner Fakültesi, Biyokimya Anabilim Dalı, Kayseri, Türkiye. \\ ${ }^{4}$ isstanbul Üniversitesi, Veteriner Fakültesi, Doğum ve Jinekoloji Anabilim Dalı, İstanbul, Türkiye. \\ ${ }^{5}$ Erciyes Üniversitesi, Veteriner Fakültesi, Doğum ve Jinekoloji Anabilim Dalı, Kayseri, Türkiye.
}

\begin{abstract}
Geliș Tarihi: 07.11.2016
Kabul Tarihi: 26.12.2016

Özet: Çalışmanın amacı, kısırlaştırılmış kedilerde krom pikolinatın (CrPic) morfometrik parametreler, ağırık artışı ile serum lipit ve leptin seviyeleri üzerine etkisinin belirlenmesidir. Kısırlaştırılıp, 2 ay adaptasyon süresini takiben çalışmaya dahil edilen 32 (22 dişi ve 10 erkek) adet, yaşları 1-5 arasında değişen ve ağırlık ortalaması $3021 \pm 453 \mathrm{~g}$ olan kediler 4 gruba ayrıldı. Kontrol grubu olarak tutulan kediler (Kontrol I), günlük enerji gereksinimi (60 kcal ME/kg) hesaplanarak ticari kuru mama ile beslendi. Ad-libitum beslenen diğer gruptaki kedilere sırasıyla CrPic kapsülden 0 (Kontrol II), 200 ya da $600 \mu \mathrm{g}$ $\mathrm{Cr} / g u ̈ n, 16$ hafta süreyle uygulandı. En fazla ağırlık artışııın belirlendiği Kontrol II'de, deri kalınlığı, abdominal çevre ve leptin düzeyinde düşük oranda bir artış gözlenirken, vücut kitle indeksi (BMI) ve göğüs çevresindeki artış önemli bulundu $(P<0.05)$. CrPic verilen gruplarda ise bu değişkenlerdeki azalma önemli değildi. Plazma leptin seviyesi ile vücut ağırlığı $(r=0.510$, $P<0.01)$ ve aterojenik indeks (AI) arasında pozitif korelasyon $(r=0.479, P<0.05)$ belirlenirken, $C r$ arasında negatif korelasyon $(r=-0.445, P<0.05)$ belirlendi. Kontrol II'de trigliserit $(T G)$, total kolesterol $(T C)$, düşük dansiteli lipoprotein $(L D L), L D L$ ve yüksek dansiteli lipoprotein (HDL) oranı ve Al değerleri en yüksek seviyede olmakla birlikte, gruplar arasında fark gözlenmedi. Krom ilavesinin de bu parametrelere önemli bir etkisinin olmadığı saptandı. Serum $\mathrm{Cr}$ ve total kolesterol düzeyleri arasında negatif ilişki belirlendi $(r=-0.468, P<0.05)$. Sonuç olarak, kısırlaştıııldıktan sonra ad-libitum beslenen tüm gruplarda canlı ağılık, BMI, deri altı yağ doku ve plazma leptin seviyesinde artış belirlenirken, krom ilavesinin bu parametrelere önemli bir etkisinin olmadığı belirlendi.
\end{abstract}

Anahtar Kelimeler: Kedi, Krom, Morfometrik ölçüm, Leptin, Lipit.

\section{Effects of Chromium Picolinate on Weight Gain, Morphometric Measurements and, Blood Lipid and}

\section{Leptin Levels in Gonadectomized Cats}

\begin{abstract}
The aim of this study was determined to the effects of chromium picolinate (CrPic) on morphometric measurements, weight gain, and serum lipid and leptin levels in gonadectomized cats. Thirty two (22 female, 10 male), aged 1-5 years, weighing $3021 \pm 453 \mathrm{~g}$, were evenly distributed into four groups following a two month adaptation period after gonadectomy. Cats in one group was kept as control (Control I) and fed commercial dry cat food at the amount providing the daily requirements of $60 \mathrm{kcal} \mathrm{ME} / \mathrm{kg}$ body weight. Cats in the remaining groups fed ad-libitum and supplemented daily with either 0 (Control II), 200 or $600 \mu \mathrm{g} \mathrm{Cr} /$ day as CrPic capsules for 16 weeks. The most marked increase in weight gain was determined in Control II in which significant increase was observed in chest circumference and body mass index $(\mathrm{BMI})(\mathrm{P}<0.05)$ whereas slightly increased levels were reported in Skinfold thickness, abdominal circumference and leptin levels. On the other hand, in the CrPic groups (200 and $600 \mu \mathrm{g} /$ day) the reported decrease in these variables were not significant. Positive correlations were found between weight gain and plasma leptin $(r=0.510$, $\mathrm{P}<0.01)$ and leptin and atherogenik indeks $(\mathrm{Al})(r=0.479, \mathrm{P}<0.05)$ while $\mathrm{Cr}$ negatively correlated with leptin $(r=-0.445$, $\mathrm{P}<0.05)$. Although differences between groups were not significant, the highest values were determined in Control II regarding triglycerides (TG), total cholesterol (TC), low density lipoprotein (LDL), LDL to high density lipoprotein (HDL) ratio and Al. It was determined that chromium supplementation did not have significant effect on these parameters. Negative relationship was determined between serum $\mathrm{Cr}$ and $\mathrm{TC}(\mathrm{r}=-0.468, \mathrm{P}<0.05)$. In conclusion, in all groups ad-libitum feeding after gonadectomy resulted to increased weight gain, BMI, subcutaneous fat deposition and plasma leptin level. There is no effect in these parameters of chromium supplementation.

Keywords: Cat, Chromium, Morphometric measurements, Leptin, Lipid.
\end{abstract}

\section{Giriş}

Sağlık ve vücut fonksiyonlarında bozulmayla sonuçlanabilen ve vücut yağ oranının artışı olarak tanımlanan obezite (Laflamme, 1997; Muğlalı 1998), küçük hayvan hekimliğinde karşılaşılan beslenme bozukluklarının en yaygın olanıdır (Ishioka ve ark., 2002). Kedi ve köpeklerin, hastalıklara neden 
olabilecek düzeyde aşırı kilolu kabul edilmelerinin ölçütleri tam olarak belirlenememiş olmasına karşın, ırk, cinsiyet ve yaşa göre ideal ağırlığının \%15'inin üzerine çıkan kediler obez olarak kabul edilir (Laflamme, 1997; Muğlalı 1998).

Kedilerde aşırı besleme, hareketsizlik ve yaşlılık gibi pekçok faktör obezitenin gelişmesini ve kilo alma eğilimini arttırır (Donoghue ve Scarlett 1998; Rand ve Martin 2004). Gonadektomi sonrası da kedilerde, harcanan enerjinin azalması ve gıda tüketiminin artması nedeniyle ağırlık artışı görülür (Fettman ve ark., 1997; Harper ve ark., 2001; Kanchuk ve ark., 2002; Nguyen ve ark., 2004). Ağırlık artışı ve vücut yapısındaki değişimler biyokimyasal ve fizyolojik parametere değişikliğine neden olur. Obezitede, adipositlerde trigliserit düzeyi artmaktadır. Adipositlerde depolanan trigliserit düzeyinin kontrolünde ise çeşitli hormonlar ve enzimler rol oynamaktadır. Gonadektomi, gonadal hormonların sirkülasyondaki düzeyini azalttı̆̆ından ya doğrudan ya da vücuttaki yağ depolarının regülasyonunda uzun dönemde etki gösteren hormonlar arasında bulunan insülin ve leptin'i etkileyerek vücut yağ kitlesinin regülasyonunu bozmaktadır (Kanchuk ve ark., 2002).

Bir obez (ob) gen ürünü olan leptin başlıca yağ doku olmak üzere ince bağırsak ve pankreasta sentezlenen ve salgılanan $16 \mathrm{kDa}$ luk bir proteindir (Nelson ve Cox, 2000). Çeşitli çalışmalarda, ağırlık artışının plazma leptin konsantrasyonunu arttırdığ belirtilmiştir (Maffei ve ark., 1995; Friedman ve Halaas, 1998). Kedilerde gonadektomiden sonra gelişen (Martin ve ark., 2001; Kanchuk ve ark., 2002), ağırlık artışıyla plazma leptin konsantrasyonunun yükseldiği (Martin ve ark., 2001; Kanchuk ve ark., 2003; Rand ve Martin, 2004) bildirilmiştir. Sağlıklı kedilerde yapılan bir başka çalışmada da (Shibata ve ark., 2003) plazma leptin düzeylerinin 0.3 ile $29.7 \mathrm{ng} / \mathrm{ml}$ arasında (ortalama 4.5 \pm 1.3 ) değiştiği ve vücut yağ oranı ile pozitif ilişkili olduğu bildirilmiştir. İnsan ve rodentlerde, kan leptin konsantrasyonunun vücut yağ oranı (Maffei ve ark.,1995) köpeklerde canlı ağırlık, vücut kitle indeksi ve vücut yağ oranı arasında bir korelasyon olduğu saptanmıştır (Shibata ve ark., 2005). Kan leptin konsantrasyonunun belirlenmesiyle yağ doku oranının doğru ve güvenilir bir şekilde ölçülebildiği bildirilmiştir (Ishioka ve ark., 2002; Shibata ve ark., 2003).

Trivalent krom $\left(\mathrm{Cr}^{3+}\right)$ insan ve hayvanlarda beslenme açısından esansiyel iz mineral olarak kabul edilir (Mertz, 1993; WHO, 1996; Anderson, 1998). Krom, insülinin etkisini artırarak karbonhidrat metabolizmasında yer aldığı gibi protein ve lipit metabolizmalarının düzenlenmesinde de rol oynar (WHO, 1996). Çeşitli hayvanlar üzerinde yapılan çalışmalar (WHO, 1996; Anderson,
1998) kromun büyüme, üreme ve immun sistem üzerinde yararlı etkilerini göstermiştir. $\mathrm{Cr}^{3+\prime}$ un vücut yapısında faydalı etkisi olmadığını belirten çalışmaların aksine (Amato ve ark., 2000; Lukaski ve ark., 2007), hayvanlar üzerinde yapılan bazı çalışmalar, kromun yağ dokuyu azalttığı ve kas dokuyu arttırdığı bildirilmiştir (Boleman ve ark., 1995; Hasten ve ark., 1997; Uyanık, 2001; Sun ve ark., 2003). Bu nedenle kromun biyolojik fonksiyonlar üzerindeki etkisini araştıran çalışmaların yapılmasına hala ihtiyaç vardır. Bu çalışmada, gonadektomize edilen ve ad-libitum beslenen kedilerde ağırlık kazancının kontrolü, deri kalınlığı, göğüs çevresi gibi morfometrik parametreler ile serum lipit ve leptin düzeylerine krom pikonatın etkisinin belirlenmesi amaçlandı.

\section{Materyal ve Metot}

Bu çalışmaya, yaşları 1-5 arasında değişen, ortalama $3021 \pm 453$ g canlı ağırıkta, melez, 22 dişi ve 10 erkek olmak üzere toplam 32 kedi dahil edildi. Çalışma sırasında Kontrol I'deki kedilerden biri çalışma dışı kaldığından çalışmaya 31 kedi ile devam edildi.

Kedilerin klinik muayeneleri yapılarak iç parazitlere karşı piperazin (Siropar srp. Adeka ${ }^{\circledR}$ ) ile $0.5 \mathrm{~g}$ niclozamid (Yomesan tablet. Bayer $^{\circledR}$ ) verildikten sonra çalışmaya dahil edilen kediler, kuduz (Rabisin, VetPet ${ }^{\circledR}$ ) ve diğer bulaşıcı hastalıklara (Feline Rhinotrachitis, Panleucopenia, Calici virüs) (Rhinopan, Biocar ${ }^{\circledR}$ ) karşı aşılandı. Kediler denemeye alınmadan önce kısırlaştırıldı (Fossum, 1997).

Kediler tamamen iyileştikten sonra Erciyes Üniversitesi Veteriner Fakültesinde bulunan barınakta $90 \times 60 \times 60 \mathrm{~cm}$ boyutlarındaki kafeslere yerleştirilerek, ortama ve mamaya alışmalarını sağlamak amacıyla herhangi bir uygulama yapılmadan iki ay beslendi. Çalışma süresince hayvanların barındırıldığı ünitede aydınlatma normal gün ışığı ile sağlandı, ortam sıcaklığının ortalama $20-22{ }^{\circ} C^{\prime}$ de tutulabilmesi için gerektiğinde termostat kontrollü elektrikli ısıtıcılardan yararlanıldı. Hayvanların suluklarında sürekli temiz su bulunduruldu. Adaptasyon süresini takiben, araştırmaya başlanmadan önce, kedilerin tekrar klinik muayeneleri yapılarak genel durumu, beden ISISI, solunum sayısı, nabız sayısı kontrol edildi. Deneme başında kedilerin ağırlıkları belirlenip grupların ağırlık ortalamalarının eşit olması sağlanarak, her grupta 8'er hayvan olacak şekilde 4 gruba ayrıldı. Tüm gruplardaki kediler, $4500 \mathrm{kcal} / \mathrm{kg}$ metabolize edilebilir enerji (ME) içeren ticari kuru kedi maması (Tablo 1) ile beslendi.

Birinci gruptaki kediler tüm araştırma süresince sağlıklı kontrol (Kontrol I) olarak tutuldu ve bu 
gruptaki kedilere günlük besin madde ihtiyacını (60$88 \mathrm{kcal} / \mathrm{kg}$ vücut ağırlı̆̆ı) (Muğlalı, 1998) karşılayacak düzeyde $(60 \mathrm{kcal} / \mathrm{kg}$ vücut ağırlığı ME) mama tartılarak bireysel yemliklere verildi. Ikinci gruptaki kediler de Kontrol (Kontrol II) olarak tutuldu ve araştırma süresince bu gruptaki kedilere mama ad-libitum verildi. Bu gruptaki kediler, ağırlık artışı kontrolü olarak tutulduklarından, deneme başı ağırlığına göre \%20 ağırlık artışı ölçüt olarak alındı.
Kedilerdeki ağırlık artışı \%20'yi geçtiğinde bu gruptaki hayvanlar fazla kilolu olarak kabul edildi. Üçüncü gruptaki kediler ad-libitum beslendi ve bu gruptaki kedilere CrPic formunda günde $200 \mu \mathrm{gr}$ (200 $\mu \mathrm{g} \mathrm{Cr}$ içeren 1 tablet, Solgar Enst., USA) 16 hafta oral yolla verildi. Dördüncü gruptaki kediler ad-libitum beslendi; bu gruptaki kedilere $\mathrm{CrPic}$ formunda günde $600 \mu \mathrm{g} \mathrm{Cr}(200 \mu \mathrm{g} \mathrm{Cr}$ içeren 3 tablet, Solgar Enst., USA) 16 hafta oral yolla verildi.

Tablo 1. Çalışmada kullanılan mamanın kimyasal bileşimi

\begin{tabular}{lccc}
\hline Kimyasal analiz değerleri & $\%$ & Etiket bilgileri & $\%$ \\
\hline Kuru madde & 96.20 & Kuru madde, en fazla & 90.00 \\
Ham protein & 32.80 & Ham protein, en az & 33.00 \\
Ham yağ & 23.10 & Ham yağ, en az & 22.00 \\
Ham kül & 6.70 & Ham kül, en fazla & 8.00 \\
Ham selüloz & 3.45 & Ham selüloz, en fazla & 3.00 \\
& & ME (kcal/kg) & 4500 \\
\hline
\end{tabular}

Tablo 2. Kedilerde krom pikolinatın ağırlık, deri kıvrım kalınlığı, göğüs ve bel çevresi, BMı ve plazma leptin düzeyine etkisi

\begin{tabular}{|c|c|c|c|c|c|}
\hline \multirow{3}{*}{ Parametre } & \multicolumn{5}{|c|}{ Krom ( $\mu \mathrm{g} /$ gün) } \\
\hline & Kontrol (I) & Kontrol (II) & 200 & 600 & $\mathbf{P}$ \\
\hline & $\mathrm{n}: 7$ & $\mathrm{n}: 8$ & $\mathrm{n}: 8$ & $\mathrm{n}: 8$ & \\
\hline \multicolumn{6}{|l|}{ Ağırlık (g) } \\
\hline Deneme başı & $2847 \pm 119$ & $3226 \pm 150$ & $3137 \pm 206$ & $2855 \pm 134$ & - \\
\hline Deneme sonu & $3234 \pm 127$ & $4199 \pm 308$ & $3853 \pm 270$ & $3620 \pm 204$ & 0.067 \\
\hline Ağırlık artışı (g) & $387 \pm 171$ & $973 \pm 193$ & $715 \pm 162$ & $765 \pm 152$ & - \\
\hline Ağırlık artışı (\%) & $14.65 \pm 6.48$ & $29.52 \pm 5.06$ & $23.21 \pm 5.20$ & $27.10 \pm 5.20$ & - \\
\hline \multicolumn{6}{|c|}{ Deri kıvrım kalınlığı (mm) } \\
\hline Deneme başı & $2.29 \pm 0.37$ & $2.72 \pm 0.43$ & $2.38 \pm 0.17$ & $2.18 \pm 0.28$ & - \\
\hline Deneme sonu & $2.74 \pm 0.29$ & $3.69 \pm 0.38$ & $2.86 \pm 0.38$ & $2.88 \pm 0.40$ & - \\
\hline \multicolumn{6}{|c|}{ Göğüs çevresi (cm) } \\
\hline Deneme başı & $26.43 \pm 1.32$ & $30.56 \pm 1.24$ & $29.50 \pm 0.90$ & $29.13 \pm 1.13$ & - \\
\hline Deneme sonu & $28.86 \pm 0.51^{b}$ & $33.63 \pm 1.36^{\mathrm{a}}$ & $31.25 \pm 1.10^{\mathrm{ab}}$ & $30.71 \pm 0.47^{a b}$ & 0.019 \\
\hline \multicolumn{6}{|c|}{ Karın çevresi (cm) } \\
\hline Deneme başı & $27.57 \pm 1.82$ & $32.44 \pm 1.46$ & $29.56 \pm 1.49$ & $28.25 \pm 1.32$ & - \\
\hline Deneme sonu & $30.28 \pm 0.99$ & $35.75 \pm 1.94$ & $33.88 \pm 2.08$ & $33.71 \pm 1.54$ & - \\
\hline \multicolumn{6}{|l|}{ Leptin (ng/ml) } \\
\hline Deneme başı & $3.05 \pm 0.39$ & $2.42 \pm 0.48$ & $2.34 \pm 0.27$ & $3.40 \pm 0.74$ & - \\
\hline Deneme sonu & $4.05 \pm 0.69$ & $6.15 \pm 0.72$ & $5.49 \pm 1.08$ & $4.24 \pm 0.84$ & - \\
\hline \multicolumn{6}{|l|}{ BMI (kg/m²) } \\
\hline Deneme sonu & $23.40 \pm 0.95^{b}$ & $28.80 \pm 1.19^{\mathrm{a}}$ & $27.11 \pm 1.10^{\mathrm{a}}$ & $26.30 \pm 1.51^{\mathrm{ab}}$ & 0.030 \\
\hline
\end{tabular}

-: önemsiz; BMI: Vücut kitle indeksi, $\mathrm{kg} / \mathrm{m}^{2}$

a-b: Aynı satırda farklı harf taşıyan değerler arasındaki fark önemlidir.

Morfometrik Ölçümler: Deneme süresince hayvanların iki haftada bir canlı ağırlıkları ölçüldü ve ad-libitum beslenen ancak $\mathrm{Cr}$ verilmeyen kontrol grubunda canlı ağırlık artışı, deneme başlangıcı ağırlığına göre, \%20'nin üzerine çıktığında hedeflenen canlı ağırlık artışının sağlandığı kabul edildi. Çalışmanın başında ve sonunda torakalumbal (göğüs-karın çevresi) genişlikleri ve her iki skapulanın hemen altından deri kalınlıkları kumpasla ölçüldü. Deneme sonunda Appleton ve ark. (2001) tarafından kediler için bildirilen formül [BMI= Canlı ağırlık (kg)/[Vücut uzunluğu $(\mathrm{m}) \times$ yükseklik $(m)$ ] ile vücut kitle indeksi (BMI) hesaplandı. Vücut uzunluğu ve yüksekliği Elliott ve ark. (2002)'nın bildirdikleri şekilde ölçüldü.

Serum ve Plazmaların Muhafazası: Deneme başı ve sonunda kedilerin $V$. jugularis'lerinden serum biyokimyasal parametreleri için $5 \mathrm{ml}$ antikoagulantsız ve leptin analizleri için $5 \mathrm{ml}$ $\mathrm{K}_{3}$ EDTA$^{\prime}$ Iı tüplere alınan kan örnekleri hemen buz içerisine konuldu ve laboratuarda plazmaları ayrıldı. Kazanılan plazmalar analizler gerçekleştirilinceye kadar $-80^{\circ} \mathrm{C}^{\prime}$ de muhafaza edildi.

Serum Analizleri ve İndeks Hesaplamaları: Serum örneklerinin trigliserit (TG), total kolesterol (TC) ve 
yüksek dansiteli lipoprotein (HDL) düzeyleri spektrofotometrik yöntemle çalışan ticari kitler (IBL', Japonya) kullanılarak, Shimatzu UV 1208 model spektrofotometre ile belirlendi. Plazma leptin düzeyi multispecies leptin kiti (Linco Research) ile saptandı. Serum LDL düzeyi Friedewald formülü [LDL=TC-(HDL+TG/5)] kullanılarak hesaplandı. Ayrıca, HDL/TC, LDL/HDL (Randal ve Gibson, 1988) ve atherogenik indeks $[\mathrm{Al}=(\mathrm{TC}-\mathrm{HDL}) /(\mathrm{HDL})]$ (Bolkent ve ark., 2006) hesaplama yoluyla belirlendi.

Krom Analizleri: Serum $\mathrm{Cr}$ düzeylerinin belirlenmesinde, matriks modifier olarak Triton $\mathrm{X}$ 100 kullanıldı. Serumlar 1:1 oranında \%0.1 triton X100 ile karıştırıldı. Kedi maması $\mathrm{Cr}$ düzeyleri ise küllendirilip nitrik asit dijesyonu yapılarak grafit fırınlı (GTA-110) Atomik Absorbsiyon Spektrofotometre (Varian AA 880) ile belirlendi.

Kedi Mamasının Besin Madde Analizleri: Kedi mamasının besin madde içeriği (ham protein, ham selüloz, ham yağ, kül, kuru madde) AOAC (1984) tarafından bildirilen metoda göre belirlendi.

Verilerin Değerlendirilmesi: Elde edilen verilerin istatistiki analizi Microsoft için SPSS 10.0 paket programı ile yapıldı. Gruplar arasındaki farkın önem kontrolü tek yönlü varyans analizi (ANOVA) ile belirlendi. Gruplar arasındaki fark önemli bulunduğunda Duncan's Multiple range test yapılarak farkın hangi gruptan kaynaklandığı belirlendi. Deneme öncesi ve deneme sonrası verilerin karşılaştırılmasında tekrarlı ölçümler için General Linear Model (GLM) kullanıldı. Kan leptin, $\mathrm{Cr}$ düzeyi ve BMI, deri kıvrım kalınlığı, göğüs ve bel çevresi ve ayrıca ölçülen biyokimyasal parametreler arasında korelasyon olup olmadığı Pearson regresyon analizi ile belirlendi. Veriler, ortalama \pm standart hata olarak verildi.

\section{Bulgular}

Kedilerde Krom Pikolinatın Morfometrik Ölçümler ve Plazma Leptin Düzeyine Etkisi: Deneme sonunda, Kontrol II'de göğüs çevresi ve BMI önemli
$(\mathrm{P}<0.05)$ oranda yüksek bulundu. Ayrıca, Kontrol I ile kıyaslandığında, ağırlık artışı $(P=0.067)$, deri kıvrım kalınlığı $(P>0.05)$, karın çevresi $(P>0.05)$ ve leptin düzeyi $(P>0.05)$ yönünden de en yüksek değerler Kontrol II'de belirlendi. Krom verilen gruplarda ise değerlendirilen parametreler Kontrol II' ye göre azaldı fakat fark önemli bulunmadı (Tablo 2). Canlı ağırlık artışı ile deri kalınlığı $(r=0.680, P<0.001)$, göğüs çevresi $(r=0.666, P<0.001)$ karın çevresi $(r=$ $0.754, P<0.001)$, BMI $(r=0.760, P<0.001)$ ve plazma leptin düzeyi $(r=0.510, P<0.01)$ arasında pozitif korelasyonlar belirlendi. Ayrıca, deri kalınlığı ile göğüs çevresi ( $r=0.501, P<0.01)$, karın çevresi ( $r=$ $0.495, P<0.05)$ ve trigliserit $(r=0.391, P<0.05)$ arasında pozitif korelasyon saptandı. Göğüs çevresi ile $\mathrm{Al}(r=0.424, \mathrm{P}<0.05)$ ve karın çevresi ile trigliserit $(r=0.382, P<0.05)$ pozitif ilişkili bulundu. Plazma leptin düzeyi ile $\mathrm{Cr}$ düzeyi $(r=-0.445, P<0.05)$ ve $\mathrm{HDL} / \mathrm{TC}(r=-0.414, \mathrm{P}<0.05)$ arasında negatif bir ilişki saptanırken leptin düzeyi ile trigliserit $(r=$ $0.521, P<0.01)$, total kolesterol $(r=0.392, P<0.05)$ ve $\mathrm{Al}(r=0.479, \mathrm{P}<0.05)$ arasında pozitif korelasyonlar belirlendi.

Kedilerde Krom Pikolinatın Serum Lipit Düzeylerine Etkisi: Serum lipit parametreleri yönünden gruplar arasında önemli bir fark saptanmadı. Ancak, Kontrol I ile kıyaslandığında Kontrol || grubunda trigliserit, total kolesterol, LDL düzeylerinin, LDL/HDL oranı ve Al değerlerinin rakamsal olarak daha yüksek ve $\mathrm{HDL} / \mathrm{TC}$ oranının ise daha düşük olduğu belirlendi. Krom verilen gruplarda trigliserit, total kolesterol ve LDL düzeyleri, Al ve LDL/HDL oranının Kontrol I ve Kontrol II gruplarındaki değerlerden düşük olduğu belirlendi (Tablo 3). Total kolesterol düzeyi ile Al arasında yüksek bir ilişki bulundu $(r=0.906$, $P<0.001)$. Leptin ile trigliserit düzeyi $(r=0.521$ $\mathrm{P}<0.01)$ ve $\mathrm{Al}(\mathrm{r}=0.479, \mathrm{P}<0.05)$ arasında pozitif, leptin ile HDL/TC arasında ise negatif $(r=-0.417$, $\mathrm{P}<0.05)$ korelasyonlar saptandı. Krom ile trigliserit ve $\mathrm{Al}$ arasında istatistiki öneme ulaşmayan, fakat $\mathrm{Cr}$ ile total kolesterol arasında ise önemli $(r=-0.468$, $\mathrm{P}<0.05$ ) negatif ilişkiler olduğu saptanmıştır.

Tablo 3. Krom pikolinatın kedilerde serum lipit düzeylerine etkisi

\begin{tabular}{|c|c|c|c|c|c|}
\hline \multirow[b]{2}{*}{ Parametre } & \multicolumn{4}{|c|}{ Krom ( $\mu \mathrm{g} /$ gün) } & \multirow[b]{2}{*}{$\mathbf{P}$} \\
\hline & Kontrol (I) n: 7 & Kontrol (II) n: 8 & $200 \mathrm{n}: 8$ & $600 \mathrm{n}: 8$ & \\
\hline TG (mg/dl) & $37.68 \pm 7.22$ & $50.06 \pm 18.58$ & $27.31 \pm 1.74$ & $33.25 \pm 7.56$ & - \\
\hline $\mathrm{TC}(\mathrm{mg} / \mathrm{dl})$ & $129.69 \pm 8.99$ & $136.53 \pm 8.48$ & $112.53 \pm 7.87$ & $122.69 \pm 11.94$ & - \\
\hline $\mathrm{HDL}(\mathrm{mg} / \mathrm{dl})$ & $80.49 \pm 1.96$ & $77.16 \pm 2.07$ & $72.54 \pm 2.66$ & $81.49 \pm 3.25$ & - \\
\hline LDL (mg/dl) & $40.71 \pm 10.38$ & $49.36 \pm 6.88$ & $32.64 \pm 7.54$ & $35.49 \pm 9.74$ & - \\
\hline LDL/HDL & $0.50 \pm 0.12$ & $0.64 \pm 0.08$ & $0.45 \pm 0.09$ & $0.42 \pm 0.10$ & - \\
\hline HDL/TC & $0.64 \pm 0.04$ & $0.58 \pm 0.03$ & $0.67 \pm 0.04$ & $0.69 \pm 0.06$ & - \\
\hline Al & $0.60 \pm 0.11$ & $0.77 \pm 0.09$ & $0.52 \pm 0.10$ & $0.50 \pm 0.11$ & - \\
\hline
\end{tabular}

-: önemsiz 


\section{Tartışma ve Sonuç}

Kedi ve köpeklerin, hastalıklara neden olabilecek düzeyde aşırı kilolu kabul edilmelerinin ölçütleri tam olarak belirlenememiş olmasına karşın, optimum ağırlığın \%15'inin üzerine çıkması durumunda kedi ve köpeklerin obez olarak kabul edildiği bildirilmiştir (Muğlalı, 1998). Deneme sonunda, adlibitum beslenen kontrol grubunda (Kontrol II), ağırlık artışı deneme başına göre \% 20'yi geçtiğinde, bu gruptaki kediler fazla kilolu olarak değerlendirildi (Laflamme, 1997). Ad-libitum beslenen CrPic gruplarında ağırlık artışı Kontrol II'den düşük olsa da, farklıı̆ı̆n önemli olmaması, insanlarda (Lukaski ve ark., 2007), domuzlarda (Page ve ark., 1993) ve koyunlarda (Uyanık, 2001) Cr'un canlı ağırlık artışını etkilemediğini bildiren araştırıcıların bulgularını desteklemektedir.

Kilo almaya bağlı olarak özellikle abdominal bölgede ve deri altında yağ doku artışı şekillendiğinden (Laflamme, 1997), bu çalışmada, istatistiki önemde olmamasına karşın en yüksek deri kıvrım kalınlığı ile karın çevresi değerleri Kontrol II de belirlendi. Bir obez (ob) gen ürünü olan ve başlıca sentez yeri yağ doku olan (Nelson ve Cox, 2000) ve yağ doku oranının doğru ve güvenilir bir göstergesi olduğu bildirilen (Shibata ve ark., 2003) leptin düzeyinde de en yüksek değer Kontrol II grubunda saptandı. Ad-libitum beslenen kontrol grubunda (Kontrol II), Kontrol l'e göre göğüs çevresi ve BMI değerinin önemli düzeyde, deri kıvrım kalınlıklarının ve leptin düzeylerinin de rakamsal olarak yüksek olması vücut yağ oranının artmasına bağlanabilir. Bu çalışmada, en yüksek leptin düzeyinin en fazla ağırlık artışı görülen Kontrol II grubunda saptanması ve ağırlık artışı, BMı ile deri kıvrım kalınlığı arasında pozitif korelasyon bulunması; kan leptin konsantrasyonu ile vücut yağ oranı arasında bir korelasyon olduğu (Martin ve ark., 2001), leptin konsantrasyonunun obezitede arttığı (Maffei ve ark.,1995) ve ağılık artışının plazma leptin düzeyini arttırdığını bildiren (Friedman ve Halaas, 1998; Kanchuk ve ark., 2003) çalışmaları desteklemektedir. Benzer şekilde, Apletton ve ark. (2000) kedilerde ağırlık artışı ile plazma leptin düzeyinde üç kat artış olduğunu, ağırık artışından önce ortalama $7.88 \pm 4.02 \mathrm{ng} / \mathrm{ml}$ olan leptin düzeyinin $24.5 \pm 12.1 \mathrm{ng} / \mathrm{ml}^{\prime}$ ye yükseldiğini bildirmişlerdir.

Ratlarda yapılan çalışmalarda, Cr'un leptin düzeyini düşürdüğü (Sun ve ark., 2000) ve böbrektestis çevresi yağ oranını azalttığı, yağsız vücut kitlesini artırdığı bildirilmiştir (Sun ve ark., 2003). Zha ve ark. (2007)'da, ratlarda 150, 300, 450 ve 600 ppb düzeylerinde nanopartikül formunda $\mathrm{Cr}^{\prime}$ un yağ oranını azalttığını, 300 ve 450 ppb düzeylerinin ise yağsız vücut kitlesini arttırdığını belirlemişlerdir. Bu çalışmada da, $\mathrm{Cr}$ verilen gruplarda göğüs çevresi değeri ve BMI'deki gerilemenin yanında, istatistiki önemde olmasa da, leptin düzeyinde görülen azalma, insanlarda ve hayvanlarda Cr'un kas kitlesini arttırarak ve/veya etkilemeyerek yağ oranını azalttığını bildiren bazı çalışmaları (Boleman ve ark., 1995; Hasten ve ark., 1997; Amato ve ark., 2000; Uyanık, 2001; Sun ve ark., 2003; Lien ve ark., 2007; Zha ve ark. 2007) desteklemektedir. Sunulan çalışmada, plazma leptin düzeyi ile krom arasındaki negatif ilişkinin yanı sıra leptin ile trigliserit arasındaki pozitif ilişki de yağ oranının azaldığını doğrulamaktadır. Bu çalışmada vücut yağ oranında meydana gelen azalma, CrPic'ın preadiposit proliferasyonu ve differensiyasyonunu baskılaması sonucu adiposit sayısının azalmasının yanında lipogenez ile ilişkili enzimlerin aktivitesinin baskılaması sonucunda trigliserit sentezinin aksamasına (Lien ve ark., 2007) bağlı olarak depo yağların azalmasından ileri gelebilir.

Yağ içeriği yüksek besi danası ve rat rasyonlarına eklenen $\mathrm{Cr}^{\prime}$ un trigliserit düzeylerini düşürdüğü belirlenmiştir (Besong ve ark., 2001; Striffler ve ark., 1998). Koyunlarda ise krom ile serum trigliserit düzeyi düşmüş; total kolesterol ve LDL düzeyi etkilenmezken, HDL-kolesterol düzeyi yükselmiştir (Uyanık, 2001). Bu çalışmada, istatistiki önemde olmasa da Kontrol II'de trigliserit, LDL ve TC düzeylerinde meydana gelen yükselmenin yanı sıra $\mathrm{HDL} / \mathrm{TC}$ oranındaki düşme ve Al oranındaki artışın BMI'deki artışla uyumlu olması kilo artışına bağlı olarak serum lipit parametrelerinde değişikliklerin oluşabileceğini bildiren çalışmaları desteklemektedir (Mennen,1998; Sunvold,1998). Matthews ve ark. (2001) domuzlarda, CrPic ve krom propionatın total kolesterol düzeylerini ve $\mathrm{HDL} / \mathrm{TC}$ oranını etkilemediğini bildirmişlerdir. $\mathrm{Bu}$ çalışmada da, total kolesterol ve LDL düzeyleri, Al, LDL/HDL ve HDL/TC oranları bakımından gruplar arasında önemli bir fark belirlenmezken, $\mathrm{Cr}$ ile total kolesterol arasında kuvvetli bir negatif ilişkinin olduğu tespit edildi.

Sonuç olarak, kedilerde gonadektomi sonrası, aşırı besleme ve hareketsizliğin ağırlık artışına yol açtığı, BMı ile deri altı yağ doku ve leptin düzeyini arttırdığı ancak; krom ilavelerinin incelenen parametrelere etkisinin zayıf olduğu belirlendi. Gelecekte değişik $\mathrm{Cr}$ bileşiklerinin farklı düzeylerinin uygulandığı, uzun süreli karşılaştırmalı çalışmaların yapılmasının yararlı olabileceği kanaatine varıldı. 


\section{Kaynaklar}

AOAC 1984: Official methods of analysis of the associaton of official analytical chemists. $14^{\text {th }}$ ed., Arlington Inc., Virginia, USA.

Amato P, Morales AJ, Yen SSC, 2000: Effects of chromium picolinate supplementation on insulin sensitivity, serum lipids, and body composition in healthy, nonobese, older men and women. J Gerontol A Biol Sci Med Sci, 55, 260-263.

Anderson RA, 1998: Recent advances in the clinical and biochemical manifestation of chromium deficiency in human and animal nutrition. J Trace Elem Exper Med, 11, 241-250.

Appleton DJ, Rand JS, Sunvold GD, 2001: Insulin sensitivity decreases with obesity and lean cats with low insulin sensitivity are at greatest risk of glucose intolerance with weight gain. J Feline Med Surg, 3, 211-228.

Besong S, Jackson JA, Trammell DS, Akay V, 2001: Influence of supplemental chromium on concentrations of liver triglyceride blood metabolites and rumen VFA profile in steers fed moderately high fat diet. J Dairy Sci, 84, 1679-1685.

Boleman SL, Boleman SJ, Bidner TD, Southern LL, Ward $T L$, Pontif JE, Pike MM, 1995: Effect of chromium picolinate on growth body composition and tissue accretion in pigs. J Anim Sci, 73, 2033-2042.

Bolkent S, Yanardag R, Bolkent S, Mutlu O, Yildirim S, Kangawa K, Minegishi Y, Suzuki H, 2006: The effect of zinc supplementation on ghrelin-immunoreactive cells and lipid parameters in gastrointestinal tissue of streptozotocin-induced female diabetic rats. $\mathrm{Mol}$ Cell Biochem, 286, 77-85.

Donoghue S, Scarrlett JM, 1998: Diet and feline obesity. $J$ Nutr, 128, 2776-2778.

Elliott DA, Backus RC, Van Loan MD, Rogers QR, 2002: Evulation of multifrequency bioelectrical impedance analysis for the assesment of extracellular and total body water in healthy cats. J Nutr, 132, 1757-1759.

Fettman NJ, Stanton CA, Banks LL, Hamar DW, Johnson DE, Hegstad RL, Johnston S, 1997: Effect of neutering on bodyweight metabolic rate and glucose tolerance of domestic cats. Res Vet Sci, 62, 131-136.

Fossum TW, 1997: Surgery of the Genital and Reproductive systems, in Small Animal Surgery, In Fossum TW (eds.) $1^{\text {th }}$ Edn, Elsevier Mosby, Philadelphia. pp: 538-574.

Friedman JM, Halaas JL, 1998: Leptin and the regulation of body weight in mammals. Nature, 395, 763-770.

Harper EJ, Stack DM, Watson TD, Moxham G, 2001: Effect of feeding regimens on bodyweight composition and condition score in cats following ovariohysterectomy. J Small Anim Pract, 42, 433438.

Hasten DL, Hegsted M, Keenan MJ, Morris GS, 1997: Dosage effects of chromium picolinate on growth and body composition in the rat. Nutr Res, 17, 11751186.
Ishioka K, Soliman MM, Sagawa M, Nakadomo F, Shibata $\mathrm{H}$, Honjoh $\mathrm{T}$, Hashimato A, Kitamura H, Kimura K, Saito $M, 2002$ : Experimental and clinical studies on plasma leptin in obese dogs. J Vet Med Sci, 64, 349353.

Kanchuk ML, Backus RC, Calvert CC, Morris JG, Rogers QR, 2002: Neutering induces changes in food intake body weight plasma insulin and leptin concentrations in normal and lipoprotein. I Nutr, 132, 1730-1732.

Kanchuk ML, Backus RC, Calvert CC, Morris JG, Rogers QR, 2003: Weight gain in gonadectomized normal and lipoprotein lipase-deficient male domestic cats results from increased food intake and not decreased energy expenditure. J Nutr, 133, 18661874.

Laflamme D, 1997: Development and validation of a body condition score system for cats. Clin Tool Feline Prac, 25, 13-18.

Lien TF, Wu CP, Horng YM, 2007: Chromium picolinate depressed proliferation and differentiation of 3T3L1 preadipocytes. Nutr Res, 27, 176-180.

Lukaski HC, Siders WA, Penland JG, 2007: Chromium picolinate supplementation in women: effects on body weight composition and iron status. Nutrition, 233, 187-195.

Maffei M, Halas J, Ravussian E, Pratley RE, Lee GH, Zhang $\mathrm{Y}$, Fei H, Kim S, Lallone R, Ranganathan S, Kern PA, Friedman JM, 1995: Leptin levels in human and rodent- measurement of plasma leptin and ob RNA in obese and weight-reduced subjects. Nat Med, 1, 1155-1161.

Martin L, Siliart B, Dumon H, Backus R, Biourge V, Nguyen $P$, 2001: Leptin body fat content and energy expenditure in intact and gonadectomized adult cats: a preliminary study. J Anim Physiol Anim Nutr, 85, 195-199.

Matthews JO, Southern LL, Fernandez JM, Pontif JE, Bidner TD, Odgaar RL, 2001: Effect of chromium picolinate and chromium propionate on glucose and insulin kinetics of growing barrows and on growth and carcass traits of growing-finishing barrows. J Anim Sci, 79(8), 2172-2178.

Mennen B, 1998: Dietary chromium: an overview. Chromium Information Bureau.

Mertz W, 1993: Chromium in human nutrition: a review. J Nutr, 123, 626-633.

Muğlalı ÖH, 1998: Beslenme Hastalıkları ve Klinik Besleme. In: "Köpek ve Kedi Besleme Beslenme Hastalıkları ve Klinik Besleme", Ed; Ergün A ve Muğlalı ÖH, Genç Büro, Ankara, Türkiye.

Nelson DL, Cox MM, 2000: Lehninger Principles of Biochemistry. $3^{\text {th }}$ ed., Worth Publishers, New York, USA.

Nguyen PG, Dumon HJ, Siliart BS, 2004: Effects of dietary fat and energy on body weight and composition after gonadectomy in cats. Am J Vet Res, 65(12), 1708-1713. 
Page TG, Southern LL, Ward TL, Thompson DL, 1993: Effect of chromium picolinate on growth and serum and carcass traits of growing-finishing pigs. J Anim Sci, 71, 656-662.

Rand JS, Martin G, 2004: Feline Obesity: causes consequences and management. In: $29^{\text {th }}$ World Congress of the World Small Animal Veterinary Association, Rhondes, Greece, pp. 382-384.

Randall JA, Gibson RS, 1988: Serum insulin and serum lipid profiles of a selected group of southern ontario tannery workers with elevated serum and urine chromium concentrations. Biol Trace Elem Res, 18, 1-8.

Shibata $\mathrm{H}$, Akahane $\mathrm{R}$, Honjoh $\mathrm{T}$, Asano $\mathrm{M}$, Mominoki $\mathrm{K}$, Fujii K, Suzuki $M$, Ohtaishi $N$, Ishioka K, Ahmed $M$, Soliman M, Kimura K, Saito M, 2005: Seasonal changes in serum leptin of the feral raccoon (Procyon lotor) determined by canine- leptinspecific ELISA. J Exp Zool,303, 7, 527-533.

Shibata H, Sasaki N, Hondjoh T, Ohishi I, TakiguchiM, IshiokaK, Ahmed M, Soliman M, Kimura K, Saito M, 2003: Feline Leptin: Immunogenic and Biological Activities of the Recombinant Protein and Its Measurement by ELISA. J Vet Med Sci, 65, 11, 12071211.

Striffer JS, Polansky MM, Anderson RA, 1998: Dietary chromium decreases insulin resistance in rats fed a high-fat mineral-ımbalanced diet. Metabolism, 4, 396-400.
Sun C, Wang S, Xia W, Sun W, 2003: Effects of chromium and fish oil on blood lipid and blood glucose in obese rats. Wei Sheng Yan Jiu, 32, 2, 110-112.

Sun C, Zhang W, Wang S, Zhang Y, 2000: Effect of chromium gluconate on body weight serum leptin and insülin in rats. Wei Sheng Yan Jiu, 29, 6, 370371.

Sunvold GD, 1998: The role of novel nutrient in managing obesity. Recent Advances in Canine and Feline Nutrition. In: lams Nutrition Symposium Proceeding, Carey DP, Norton SA and Bolser SM eds. Wilmington $\mathrm{OH}$, Orange Frazer Press, 2, 123-133.

Uyanık F, 2001: The effects of dietary chromium supplementation on some blood parameters in sheep. Biol Trace Elem Res, 84, 93-101.

World Health Organisation (WHO), 1996: Chromium. Genova, 155-159.

Zha LY, Xu ZR, Wang MQ, Gu LY, 2007: Effects of chromium nanoparticle dosage on growth body composition serum hormones and tissue chromium in Sprague-Dawley rats. J Zhejiang Univ Sci B, 85, 323-330.

**: Bu çalışma Erciyes Üniversitesi Bilimsel Araştırma Projeleri Birimi tarafindan (EUBAP VA-05-12) desteklenmiştir.

*Yazışma Adresi: Berrin KOCAOĞLU GÜÇLÜ

Erciyes Üniversitesi, Veteriner Fakültesi, Hayvan Besleme ve Beslenme Hastalıkları Anabilim Dalı, Kayseri, Türkiye.

e-mail: berrinkg@hotmail.com 